\title{
Science in the 80s: the need for political involvement
}

DD: Ten years ago you wrote about the "party being over"' for scientists. How do you feel that statement has worked out? SW: Throughout the 1970s it has been more difficult for scientists to get money; to that extent my prediction was broadly right. In particular, the gradual reduction in per capita spending on the universities has meant that the British research councils have had to find a greater proportion of the total research expenditure than was the case in the golden years of the late 1950s and early 1960s. But I hadn't at the time thought that not only would the party be over, but that those who went to the party would be spending their time cleaning up afterwards - which seems to be the situation now. I hoped that we could get back to a steady, albeit modest, rate of growth, at least for the research councils; it's now clear that we will not see what I was hoping would be about a $3-4 \%$ real growth rate per annum over four to five years.

DD: What has been the main impact of economic stringencies in political terms?

SW: So far, the science budget has not tended to be very involved in either the politics of being cut or being expanded. It tends to stand slightly outside the rest of the political process, and therefore to run along with whatever is the overall tendency. In a period of expansion, the science budget tends to grow alongside; similarly it tends to contract during a period of contraction. And one of the things I was very anxious to do - and just succeeded in doing towards the end of my time as Secretary of State - was to cut the linkage between seeing the science budget as, in a sense, merely another expression of the "science and education" budget. I thought it had to be treated separately, because it had quite different cases to be made for it. I don't believe, for example, that the science budget is appropriately linked to the massive impact of demographic trends, on the education budget, whether rising as in the late 60 s or now declining.

DD: What type of arguments did you use in Cabinet a year ago to obtain support for increased funding for research?

SW: I tried to explain in ways that would be understandable to the non-scientist - and to some extent I used myself as a litmus paper - what was going on in science, and what the prospects were for reasonable breakthroughs in some fields, or at least for some very fruitful work. Examples might be the work on laser technology being carried out by the Science Research Council, or the Medical Research Council's work in fields such as senile dementia and schizophrenia, research which offered some prospect of making
As Secretary of State for Education and Science in the last Labour Government, Mrs Shirley Williams (below) took an above average interest in the health of the scientific community. David Dickson talked recently to her at Harvard University, where she has just been a visiting fellow

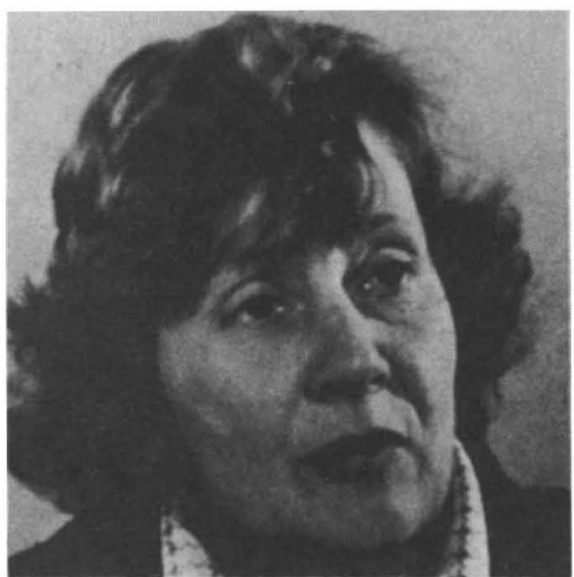

substantial savings in the health service in the future, if one could find ways of treating people outside mental hospitals.

The idea was not necessarily to say "this is what the work being done is about" but rather "these are examples which readily lend themselves to being thought about in terms of their impact on other people's programmes". I didn't feel there had been a sufficient attempt to explain the research council's activities, as distinct from saying "here's the science budget; I want a $2 \%$ growth for it". In other words, there had not really been an argument about the priorities for scientific research as against the priorities for other things, such as defence or social security.

My own belief is that, although scientists don't like to think that research is involved in the political process, it has to be, at least to the extent that science is explained as proselytised about. It wasn't really necessary at the time of the great Robbins expansion of higher education in the 1960s, because the dual support system bore the expansion on its back. Now that system is threatened by demographic shifts, as well as the general cutting back of the higher education budget - which makes it important for scientists and the research councils to learn to put across what they are doing, and build up a lobby of support.

DD: Turning to the social aspects of scientific growth, how do you feel the relationship between the scientific community and the political community has changed in the 70s?

SW: In the narrow sense of the two communities, I would firstly sum it up by saying that the scientific community resisted getting involved, or even communicating much, with the political community, and it certainly seemed to me that such communication was very important. The process under which, for example, the science and technology committee of the House of Commons has tended to cross-question civil servants, and even to some extent the heads of research councils - even though the witnesses sometimes feel they are not revealing vast knowledge - will only work effectively if scientists are willing to make themselves available to the political community. I would criticise scientists in Britain by saying that, in general, they have not been all that readily available, and have been a bit suspicious of people taking time off from the lab to talk to "those amateurs out there". I think that's rather a mistake.

DD: You have frequently suggested that there should be more of a scientific lobby. Do you feel there has been any movement in this direction?

SW: A little. The research councils, and particularly the heads of the research councils, have done much more to come out and explain what they are doing. And insofar as the barriers between the sciences are beginning to break down - for example through joint research projects between the different councils - as well as to some extent the barriers between the scientists and the press, then the research councils are pushing in the right direction. DD: But once money begins to get tight, are you not required to make a better case justifying support?.

SW: Yes, and I think that's right. One parallel that has always struck me forcefully is that you could increase the arts budget by $15 \%$, and the entire arts lobby would shout its head off about how mean it was, because they always want at least $25 \%$ increase a year. But if you increase the science budget by $5 \%$ in real terms - say 11 or $12 \%$ in money terms - scientists would always be rather grateful. Now I think that the arts lobby overdid it, but they have a large lobby of people who will write letters to the newspapers, speak in the House of Lords, and so on. The scientists - who, thank goodness, are at long last beginning to appear in the Houses of Parliament are not so ready, don't react so quickly, don't fight so hard. I wouldn't want to push it so far as the arts lobby does, which may even be slightly counterproductive, but I still think there is something to be said for closing the gap a bit. 
DD: How do you feel about the way that concerns about the social impacts of science have been institutionalised - the Genetic Manipulation Advisory Group is the obvious example - and of the way that the scientific community has responded.

SW: There have been many types of responses. GMAG is only one example, and indeed the fact that the Association of Scientific, Technical and Managerial Staffs recently held a conference on GMAG is a good example of how questions about the social impacts of science have been spread beyond the small community of scientists and administrators that directly interweave with them. The Windscale Inquiry is another good example, which was rather well handled, if one compares it with some of the tremendous clashes that there have been in France and Germany. The whole idea of having an inquiry of that kind, with a judge in charge, but passing the conclusions on to the House of Commons for a free vote, was rather an innovative way of going about an area where science and social policy come up against one another.

One example where this went badly was in the area of dangerous pathogens - the smallpox case at the Univeristy of Birmingham; and that was because the dangerous pathogens' rules and regulations pre-date public interest in the field of science and social policy, so that what we had was a relatively secretive and relatively unpublicised system of control and regulation. Immediately something went wrong, the Shooter Report on the smallpox case was able to pinpoint all sorts of holes in the system, because it hadn't really been looked at. People had become complacent about it; it wasn't within the light of the public domain. GMAG was; nuclear power to some extent is, although I would like to see a broader range of public interest brought in; and this is also particularly true in the area of advanced medical science.

As for GMAG, as a device for meeting public concern and, in the initial stages, for allowing experiments to be conducted in closely controlled situations, it had a great deal to be said for it. As a step into a whole new area of science with a great number of public fears associated with it, you only needed to have one accident for the whole of genetic engineering to be at great risk, and for some parliamentarians to say "ban the lot". Indeed there was quite a strong move in Parliament to say that we should not do some of the experiments that fell into the containment categories. And so although I know now that some scientists, and even more industrialists, would criticise GMAG as being exceptionally restrictive, nevertheless as a way of showing that public fears were being taken seriously it was an important beginning. The risks may be low; but what's at stake is so high that the risk-benefit equation does involve a great deal.

What bothers me about the US is that the controls and regulations, such as they have been - I use that tense advisedly - do not really extend very much into the private sector. And, of course, there are countries, such as Switzerland, where the private sector is relatively unregulated. Given that what we are looking at should be an international system of regulation - you can erect national systems, but what difference does that make to a virus? - one has to make some sort of a compromise. I realise that it would almost certainly not be as rigorous as the current GMAG rules to be widely acceptable, but one hopes it would have rather more sensible safeguards, especially with regards to category III and category IV experiments. Britain might have a more regulated national system than some other countries; but the general principles of good practice at the bottom end and pretty strict regulation at the top end is something we ought to try to get across through the European Science Foundation, and in other ways.

DD: The US is currently experiencing a political reaction against regulation, and is caught in the trap while move is being learnt about potential environmental and health hazards, the less regulation becomes politically acceptable. How do you correlate social and political needs?

SW: The way I see it, the US often needs regulation to help make sense of its legislation, which has often been cast in the form that will generate sufficient support - legislation emerging from a process of creating a coalition to get it through. Regulation then becomes the way that you rationalise this rather strange cross-path of legislation. If one takes the fields of education or employment - or for that matter safety and health - one finds that the regulations are extremely detailed and precise, but that they are often changed and amended in the light of events. So that you find people responsible for regulation almost going round the bend with the sheer weight, change and detail of the regulation. And that, in turn, leads to the kind of antithesis of people like Senator Edward Kennedy, for all that he is a liberal senator, moving against regulation.

DD: How do you see the future prospects for science in Britain? What are the new political pressures likely to be in the 1980s?

SW: One important need is for the leaders of the scientific community to get across the idea of lead-times; in other words, to try to get agreement as far as possible that a substantial chunk of the budget ought, as far as possible, to be insulated from yearto-year changes. I'd like to see the budget split between extra money that could be used quickly, and money which requires to be committed for some time, since one of the most difficult things to do is to set up a team of people and then to discover a year or two later that the team is chopped off from its funds, or from half of its funds, just when it is getting going.

Secondly it is important to move in the direction that Geoffrey Allen of the SRC talks about, namely providing fellowships on a four- or five-year basis for young scientists. I am very concerned that the profile of the academic world is such that unless we are very careful, some of the most able of the new generation of young scientists will not get jobs in universities. DD: But looking at the question the other way round, what new challenges can you see science having to face from the political body - or from the social body - to which it will have to respond?

SW: One area in which a great deal of thought is needed is the extent to which the 'sophistication factor' is likely to have an impact on certain major areas of public finance, particularly in health. A scientist once said to me that if heart transplants had been generally successful, the National Health Service would be in even more trouble than it is, and that seems to me correct. We should be worrying whether the sophistication factor, particularly in medicine, will in practice mean that one is budgeting against the needs of the great majority of the population. It is extremely important to notice how anti-distributive the effects of advanced medical technology can be. Look at the US where medicine has become so expensive because of the technology that, in practice reasonably decent intermediate technology medicine is out of the range of part of the population.

I believe that the government particularly people concerned with the health field, though pensions and mental health also come into this - should decide, together with scientists, what profile of research is likely to ease the position of hard-pressed health budgets, and what research is likely to make it worse.

People should be aware of the costs as well as the benefits of successful research. Even in the US, in the discussions that I have followed here on medical insurance schemes, almost nobody has taken up the theme of the massive consequences of rapidly advancing medical technology in terms of health care. If I can be blunt, I think that in ten years time it will be impossible to finance any effective public medical service in the US, because a great range of less expensive but reasonably effective technologies will have been ruled out.

DD: Does this mean you see the science budget more and more closely linked to other areas of government spending and social policy? How can the social impact issues be brought into the policy process? SW: I think that it has to be done at every level. Certainly the research councils should take such matters into consideration. But one would also have to have a kind of parallel system, parallel meetings of interest groups in the House of Commons and in the mass media. This would mean the scientific community being brought together with economists and social scientists more often to look at the implications of certain advances. 